\title{
Development and Reproduction of Podisus nigrispinus (Hemiptera: Pentatomidae) Fed with Thyrinteina arnobia (Lepidoptera: Geometridae) Reared on Guava Leaves
}

\author{
Harley Nonato de Oliveira*, Marcelo Curitiba Espindula², Marcela Marcelino Duarte ${ }^{3}$, \\ Fabrício Fagundes Pereira ${ }^{3}$ and José Cola Zanuncio ${ }^{4}$ \\ ${ }^{1}$ Embrapa Agropecuária Oeste; C. P.: 661; 79804-970; Dourados - MS - Brasil. ${ }^{2}$ Departamento de Fitotecnia; \\ Universidade Federal de Viçosa; 36571-000; Viçosa - MG - Brasil. ${ }^{3}$ Faculdade de Ciências Biológicas e \\ Ambientais; Universidade Federal da Grande Dourados; Rodovia Dourados - Itahum, km 12, 79804-970; \\ Dourados - MS - Brasil. ${ }^{4}$ Departamento de Biologia Animal; Universidade Federal de Viçosa; 36571-000; Viçosa - \\ $M G$ - Brasil
}

\begin{abstract}
The aim of this study was to evaluate the development and reproduction of $\mathrm{P}$. nigrispinus in laboratory when fed with T. arnobia reared on guava leaves. This predator showed nymphal stage of 21.11 days, survival of $60 \%$ and periods of pre-oviposition, number of eggs/mass and eggs/female and egg viability of 6.10 days, 26.24 eggs, 314.90 eggs and $82.65 \%$, respectively. These results demonstrated that T. arnobia fed with guava leaves was an adequate supply of food to P.nigrispinus.
\end{abstract}

Key words: biological control; defoliator; stinkbug

\section{INTRODUCTION}

Predators of the genus Podisus are natural enemies used for biological control. They occur in the entire American Continent (Thomas, 1992) and have been found in agriculture and forest areas in Brazil (Zanuncio et al., 1993). Podisus nigrispinus (Dallas, 1851) (Heteroptera: Pentatomidae), one of the most common species of this genus in the Neotropical areas, was reported in Brazil at Espírito Santo, Maranhão, Minas Gerais, Mato Grosso do Sul, Pará and São Paulo States. This species has been found in the following crops: cotton, coffee, eucalyptus, pinus, corn, soybean and wheat (Guedes et al., 2000; Pereira et al., 2001).

The brown eucalyptus caterpillar Thyrinteina arnobia (Stoll, 1782) (Lepidoptera: Geometridae) is one of the most important defoliator of Eucalyptus spp., Psidium guajava, Campomanesia spp. and Eugenia spp. (Oliveira et al., 2005). Outbreaks of this species in forest plantations have been controlled, in some situations, with insecticides. However, insecticides may kill natural enemies (Guedes et al., 1992) and contaminate the environment. Therefore, there is a need to develop alternative control methods for this pest (Zanuncio et al., 1991). Due to the facility

*Author for correspondence: harley@ cpao.embrapa.br 
of rearing predatory stinkbug in laboratory, these insects have been produced and released in biological control programs of defoliating caterpillars (Zanuncio et al., 2002).

However, this approach may decrease their efficiency in the field because the stimuli they receive in mass rearing are different from those in natural prey. Therefore, biological aspects of these predators can be adversely affected (Sznajder and Harvey, 2003). The knowledge about the performance of $P$. nigrispinus reared on natural prey is important not only to obtain the information about this predator on another host, but also to obtain data on its establishment in areas with the culture.

Holtz et al. (2007) evaluated the performance of $P$. nigrispinus fed with $T$. arnobia caterpillars and demonstrated that this predator was not adapted to that prey when reared on eucaliptus leaves. The adaptation of herbivore in differents hosts has been the subject of ecological studies (Agrawal, 2000). However, low attention has been given to the investigation about how the predators can adapt to the prey when them come from differents kind of host. The main of this study was to evaluate the development and reproduction of $P$. nigrispinus in laboratory, when fed with $T$. arnobia reared on guava leaves.

\section{MATERIALS AND METHODS}

\section{Rearing the prey Thyrinteina arnobia}

Caterpillars of T. arnobia were obtained from a mass rearing at Entomology Laboratory of Federal University of Espirito Santo. The pupae were conditioned in PVC tubes with $200 \mathrm{~mm}$ diameter and $25 \mathrm{~cm}$ height. The adults of T. arnobia were transferred just after emergence to a $38 \times 41 \times 45$ $\mathrm{cm}$ wood box with paper leaf in its internal wall as oviposition site. A glass door was put on one side of this box to facilitate the handling of the insects. These adults received a $10 \%$ honey solution in anesthetic tube type and their egg masses were daily collected and maintained in an acclimatized chamber at $25 \pm 3^{\circ} \mathrm{C}$, relative humidity of $70 \pm$ $10 \%$ and photo phase of $12 \mathrm{~h}$. The eggs of $T$. arnobia were maintained in Petri dishes $(9.0 \times 1.2$ $\mathrm{cm})$ until emergence of the caterpillars that were transferred to plastic tubes $(15 \times 12 \mathrm{~cm})$ with the leaves of guava (Psidium guajava) until the pupa stage.
Maintenance and multiplication of the predator Podisus nigrispinus

$P$. nigrispinus was reared in an acclimatized room at $25 \pm 3^{\circ} \mathrm{C}$, relative humidity of $70 \pm 10 \%$ and photophase of $14 \mathrm{~h}$. Ten adults of $P$. nigrispinus were maintained in plastic cup of $500 \mathrm{ml}$ with absorbent paper as oviposition site. Water was supplied in an anesthetic tube type fixed at the cover of these cups and with its extremity locked with cotton. $P$. nigrispinus was fed with Tenebrio molitor (Linnaeus, 1758) (Coleoptera: Tenebrionidae) larvae.

\section{Laboratory experiment \\ Stage I}

A total of 80 replications were used in which each one was constituted by an individualized second instar $P$. nigrispinus nymph in a Petri dish $(9.0 \mathrm{x}$ $1.5 \mathrm{~cm})$. A cotton pad $(3 \times 3 \mathrm{~cm})$ was put on the inside top of each dish and daily moistened with distilled water to maintain the humidity and water supply for these nymphs. The inferior part of the dishes was covered with paper filter to absorb the excess humidity. P. nigrispinus nymphs received fourth instar larvae of $T$. arnobia, which were replaced when necessary.

\section{Stage II}

Twenty pairs of recently emerged $P$. nigrispinus adults were obtained from the stage I. Each of these pairs was conditioned in a plastic cup (9.5 $\mathrm{cm}$ height and $10 \mathrm{~cm}$ diameter). An anesthetic tube type was put the inside cover of these cups with its extremity locked with a cotton pad to supply water to the insects. The internal part of these cups was wrapped with paper as oviposition site. These adults received caterpillars of $T$. arnobia which were replaced when necessary.

\section{Statistical analysis}

The weight and weight gain was observed for the each instar and up to the third day of the adult stage (males and females). The duration and viability of each instar of $P$. nigrispinus were also evaluated. The pre-oviposition period, the numbers of egg masses, eggs per egg mass, eggs per female and nymphs per egg mass besides the viability of eggs per egg mass per female of $P$. nigrispinus were evaluated. The analyses of variance at 5\% probability level were performed for all the characteristics investigated. 


\section{RESULTS AND DISCUSSION}

The weight of the nymphs of $P$. nigrispinus, independent of gender (male and female), were similar in the second, third and fourth instar (Table 1). However, the females from the fifth instar were heavier than males. Gain of weight during the second, third and fifth instars for nymphs which originated the females or males of $P$. nigrispinus were similar (Fig. 1A). However, gain of weight was higher for the females in the fourth instar compared to the males.

The males and females of this predator lost weight on the first day of the adult stage, which continued for the males on their second day of life. On the other hand, $P$. nigrispinus females had approximately $8 \%$ gains of weight during this period (Fig. 1B). Heavier weight of $P$. nigrispinus nymphs at the end of the nymph period for those that originated females and in the adult stage was similar to that found for Podisus distinctus (Stal, 1860) (Heteroptera: Pentatomidae) fed with $T$. molitor larvae (Zanuncio et al., 1998; Matos Neto et al., 2004) and to $P$. nigrispinus fed with Zophobas confusa Gebien, 1906 (Coleoptera: Tenebrionidae) larvae (Zanuncio et al., 1996). This higher weight of the females than males was due to biomass accumulation by the females, which was necessary for their reproduction from the beginning of the fifth instar. Weight gain by the females of predatory Pentatomidae has also been related to the development of their ovary and egg formation (Oliveira et al., 1999; Oliveira et al., 2002).

Table 1 - Nymphs of weight (mean \pm standard error) in the second, third, fourth and fifth stages and adults until the third day (mg) of Podisus nigrispinus with Thyrinteina arnobia $\left(25 \pm 3^{\circ} \mathrm{C}, \mathrm{RH} 70 \pm 10 \%\right.$ and photophase of 12 hours).

\begin{tabular}{ccccc}
\hline Instar & $\begin{array}{c}\text { Females } \\
\text { Weight }(\mathbf{m g})^{*}\end{array}$ & Range of average & $\begin{array}{c}\text { Males } \\
\text { Weight }(\mathbf{m g})\end{array}$ & Range of average \\
\hline II & $0.73 \pm 0.22 \mathrm{a}$ & $(0.6-0.9)$ & $0.74 \pm 0.02 \mathrm{a}$ & $(0.6-0.9)$ \\
III & $3.14 \pm 0.17 \mathrm{a}$ & $(2.4-4.4)$ & $3.21 \pm 0.30 \mathrm{a}$ & $(2.3-6.8)$ \\
IV & $10.20 \pm 0.97 \mathrm{a}$ & $(6.2-16.2)$ & $9.91 \pm 1.00 \mathrm{a}$ & $(6.2-18.6)$ \\
V & $29.95 \pm 2.51 \mathrm{a}$ & $(15.9-46.5)$ & $22.42 \pm 0.89 \mathrm{~b}$ & $(17.9-30.1)$ \\
$1^{\mathbf{o}}$ adult day & $65.39 \pm 1.74 \mathrm{a}$ & $(51.7-75.4)$ & $45.61 \pm 1.64 \mathrm{~b}$ & $(35.4-68.5)$ \\
$2^{\circ}$ adult day & $64.23 \pm 4.27 \mathrm{a}$ & $(33.1-85.0)$ & $41.20 \pm 2.08 \mathrm{~b}$ & $(26.4-50.5)$ \\
$3^{\circ}$ adult day & $69.21 \pm 4.95 \mathrm{a}$ & $(41.9-111.7)$ & $40.30 \pm 2.36 \mathrm{~b}$ & $(27.7-57.0)$ \\
\hline
\end{tabular}

* Means followed by the same letter in the line are not different at $5 \%$ of probability.

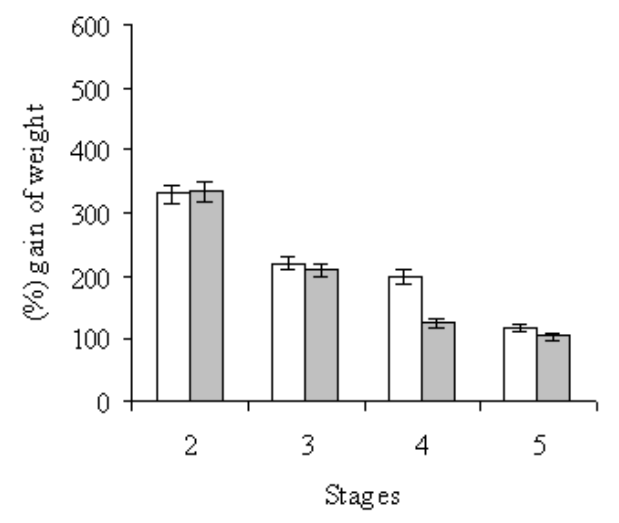

(A)

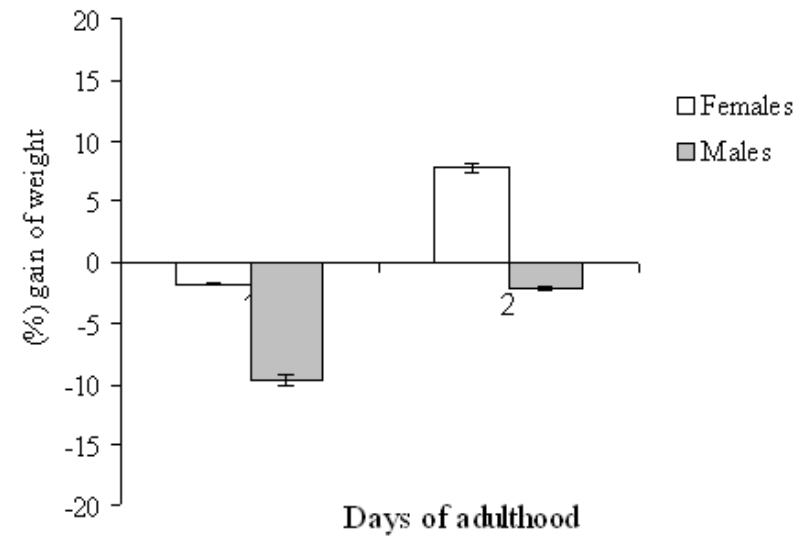

(B)

Figure 1 - Gain of weight (\%) of females and males of Podisus nigrispinus the second, third, fourth and fifth stages (A) and the first and second days of adulthood (B) fed with larvae Thyrinteina arnobia. $25 \pm 3^{\circ} \mathrm{C}, \mathrm{RH} 70 \pm 10 \%$ and photophase of 12 hours. 
Duration from second to fifth instar (5.18 to 6.89 days) of P. nigrispinus was similar to that of 4.1 to 6.7 days for this predator fed with Musca domestica (Linnaeus, 1758) (Diptera: Muscidae) larvae and 3.4 to 6.0 days with Bombyx mori (Linnaeus, 1758) (Lepidoptera: Bombycidae) larvae (Zanuncio et al., 1990). These values were also similar for this predator with different prey because it presented duration of each instar from 3.3 to 6.9 days with Rachiplusia nu (Guenée, 1852) (Lepidoptera: Noctuidae) (Saini, 1994) larvae and 3.4 to 6.2 days with Alabama argillacea (Huebner, 1818) (Lepidoptera: Noctuidae) caterpillars (Oliveira et al., 2002). The duration of 21.11 days for the nymph stage of $P$. nigrispinus (Table 2) was similar to that of this predator fed Spodoptera frugiperda (J.E. Smith, 1797) (21.6 days) and T. molitor pupae (20.4 days) (Oliveira et al., 2004). These results also showed that $T$. arnobia larva was an adequate prey to meet the development and reproduction requirements of P. nigrispinus.
The nymph viability of each instar of $P$. nigrispinus (Table 2) was similar to that found for this predator with caterpillars of $B$. mori $(85$ a 96\%) from the second until fifth nymphal stage (Fernandes et al., 1996). The total viability $(60 \%)$ was also similar when this predator were fed with S. frugiperda (64\%) and with T. molitor (68\%) (Oliveira et al., 2004).

The longevity of $P$. nigrispinus was 35.54 days for the females and 43.08 days for the males (Table 3 ). The shorter longevity of $P$. nigrispinus females than the males when fed with $T$. arnobia caterpillars agreed with that reported for this predator fed with $S$. frugiperda larvae (39.6 days) (Oliveira et al., 2004). It could be explained by the high energy use of the females for egg formation and oviposition. This occurs due to different energy allocation between the physiological processes with increase of one energy demand for egg production and decrease for maintenance (i.e. longevity) (Sibly and Calow, 1986).

Table 2 - Duration of the nymphal stages and (days) (mean \pm standard error) of Podisus nigrispinus fed Thyrinteina arnobia. $25 \pm 3{ }^{\circ} \mathrm{C}, \mathrm{RH} 70 \pm 10 \%$ and photophase of 12 hours.

\begin{tabular}{cccc}
\hline Instar & Duration (days) & Range of average & Viability (\%) \\
\hline II & $5.18 \pm 0.21$ & $(3-9)$ & 86 \\
III & $4.61 \pm 0.11$ & $(4-6)$ & 86 \\
IV & $4.43 \pm 0.16$ & $(3-7)$ & 95 \\
V & $6.89 \pm 0.22$ & $(6-11)$ & 86 \\
Total & $21.11 \pm 0.52$ & $(18-27)$ & 60 \\
\hline
\end{tabular}

Table 3 - Mean \pm standard error of biological aspects of Podisus nigrispinus adults fed with Thyrinteina arnobia in the laboratory $\left(25 \pm 3{ }^{\circ} \mathrm{C}\right.$, RH $70 \pm 10 \%$ and photophase of 12 hours).

\begin{tabular}{lcc}
\hline Parameters & Podisus nigrispinus & Range of average \\
\hline Pre-oviposition (days) & $6.10 \pm 0.91$ & $(2-11)$ \\
Number of eggs/females & $314.90 \pm 59.31$ & $(121-679)$ \\
Egg viability (\%) & $82.65 \pm 1.33$ & $(22-100)$ \\
Longevity (females) & $35.54 \pm 3.02$ & $(19-61)$ \\
Longevity (males) & $43.08 \pm 4.72$ & $(17-65)$ \\
\hline
\end{tabular}

The pre-oviposition period per female of $P$. nigrispinus was 6.10 days (Table 3 ), which was similar to 6.3 days found for this predator in $T$. arnobia reared in eucalyptus leaves (Holtz et al., 2006) and with A. argillacea caterpillars (Oliveira et al., 2002). The number of eggs per female of $P$. nigrispinus fed with $T$. arnobia (314.90), was similar to that found for this predator when fed with $A$. argillacea caterpillars and cotton crop
$(348,10)$ (Oliveira et al., 2002) and with T. molitor $(296,66 ; 325,00)$ (Espindula et al., 1996; Oliveira et al., 2004) and higher than that when fed with Diatraea saccharalis (Fabricius, 1794) (Lepidoptera: Crambidae) $(97,12)$ (Vacari et al., 2007) and with T. arnobia (57.0) reared with eucalyptus (Holtz et al., 2006; 2007). The highest number of eggs found for $P$. nigrispinus when fed with A. argillacea and cotton crop on T. molitor 
larvae and with caterpillars of $T$. arnobia reared in guava leaves, suggested that these preys may have better nutritional requirements for $P$. nigrispinus. Eggs viability of this predator was $82.65 \%$ (Table 3 ), which was higher than that reported by Holtz et al. (2006) for P. nigrispinus fed with T. arnobia $(56.4 \%)$, when reared with eucalyptus leaves. In T. molitor $(79.2 \%)$ and S. frugiperda $(85.2 \%)$ (Oliveira et al., 2004), results were similar showing that $P$. nigrispinus fed with $T$. arnobia from guava leaves had adequate nutritional quality.

Results showed that $T$. arnobia reared on guava leaves could be an appropriate prey to $P$. nigrispinus. Holtz et al. (2007) reported that this caterpillar reared on eucalyptus leaves was not a good prey, because these leaves had a specific essence which produced secondary substances, which might affect stinkbug development. However, Holtz et al. (2003) evaluated the effect of these substances on T. arnobia and found that these compounds did not affect the development of this caterpillar on eucalyptus, but others substances that come from guava could affect their development. Santos et al. (2000) and Oliveira et al. (2005) found that T. arnobia had better development on guava leaves, which could be considered as the best host for it, while eucalyptus leaves had poor digestibility and nutritional quality which reduced the development of this caterpillar. For this reason, when T. arnobia was reared with eucalyptus leaves, probably the larvae had a lower quality and therefore affected the development of the predator.

\section{ACKNOWLEDGEMENTS}

We thank to Conselho Nacional de Desenvolvimento Científico e Tecnológico $(\mathrm{CNPq})$ for the financial support.

\section{REFERENCES}

Agrawal, A.A. (2000), Specificity of induced resistance in wild radish: causes and consequences for two specialist and two generalist caterpillars. Oikos, 89, 493-500.
Espindula, M.C.; Oliveira, H.N.; Campanharo, M.; Pastori, P.L.; Magevski, G.C. (2006), Influência da massa corporal sobre características reprodutivas e longevidade de fêmeas de Podisus nigrispinus (Dallas) (Heteroptera: Pentatomidae). Idesia, 24, 1925.

Fernandes, L.G.; Carvalho, C.F.; Bueno, V.H.P.; Diniz, L.C. (1996), Aspectos biológicos de Brontocoris tabidus Signoret, 1852 e Podisus nigrispinus Dallas, 1851 (Hemiptera: Pentatomidae). Rev. Cerne, 2, 115.

Guedes, R.N.C.; Lima, J.O.G.; Zanuncio, J.C. (1992), Seletividade dos inseticidas deltametrina, fenvalerato e fenitrition para Podisus connexivus Bergroth, 1891 (Heteroptera: Pentatomidae). An. Soc. Entomol. Bras., 21, 339-346.

Guedes, R.N.C.; Zanuncio, T.V.; Zanuncio, J.C.; Medeiros, A.G.B. (2000), Species richness and fluctuation of defoliator Lepidoptera populations in Brazilian plantations of Eucalyptus grandis as affected by plant age and weather factors. For. Ecol. Manag., 137, 179-184.

Holtz, A.M.; Oliveira, H.G.; Pallini, A.; Venzon, M.; Zanuncio, J.C.; Oliveira, C.L.; Marinho, J.S.; Rosado, M.C. (2003), Desempenho de Thyrinteina arnobia Stoll (Lepidoptera: Geometridae) em eucalipto e goiaba: o hospedeiro nativo não é um bom hospedeiro? Neotrop. Entomol., 32, 427-431.

Holtz, A.M.; Zanuncio, J.C.; Marinho, J.S.; Pratissoli, D.; Pallini, A.; Pereira, C.J. (2006), Características biológicas de adultos de Podisus nigrispinus e Supputius cincticeps (Hemiptera: Pentatomidae) alimentados com Thyrinteina arnobia (Lepidoptera: Geometridae). Idesia, 24, 41-418.

Holtz, A.M.; Zanuncio, J.C.; Oliveira, C.L.; Pratissoli D.; Pallini A.; Marinho, J.S.; Vianna, U.R. (2007), Potencial reprodutivo e de sobrevivência de Podisus nigrispinus Dallas (Heteroptera: Pentatomidae) sobre Thyrinteina arnobia Stoll Lepidoptera: Geometridae) e Tenebrio molitor L. (Coleoptera: Tenebrionidae). Floresta, 37, 63-70.

Matos Neto, F.C.; Oliveira, H.N.; Zanuncio, J.C.; Holtz, A.M. (2004), Ganância de peso del depredador Podisus distinctus (Heteroptera: Pentatomidae) em combinaciones de las presas Tenebrio molitor (Coleoptera: Tenebrionidae) y Musca domestica (Diptera: Muscidae). Rev. Biol. Trop., 52, 1-8.

Oliveira, H.N.; Pratissoli, D.; Pedruzzi, E.P.; Espindula, M.C. (2004), Desenvolvimento do predador Podisus nigrispinus alimentado com Spodoptera frugiperda e Tenebrio molitor. Pesq. Agropec. Bras., 39, 947-951. 
Oliveira, H.N.; Zanuncio, J.C.; Pedruzzi, E.P.; Espindula, M.C. (2005), Rearing of Thyrinteina Arnobia (Lepidoptera: Geometridae) on guava and eucalyptus in laboratory. Braz. Arch. Biol. Technol., 48, 801-806.

Oliveira, H.N.; Zanuncio, J.C.; Sossai, M.F.; Pratissoli, D. (1999), Body weight increment of Podisus nigrispinus (Stal) (Heteroptera: Pentatomidae), fed on Tenebrio molitor L. (Coleoptera: Tenebrionidae) or Musca domestica L. (Diptera: Muscidae). Brenesia, 51, 77-83.

Oliveira, J.E.M.; Torres, J.B.; Carrano-Moreira, A.F.; Barros, R. (2002), Efeito das plantas de tomateiro, como complemento alimentar, no desenvolvimento e na reprodução do predador Podisus nigrispinus (Dallas) (Heteroptera: Pentatomidae). Neotrop. Entomol. 31, 101-108.

Pereira, J.M.M.; Zanuncio, T.V.; Zanuncio, J.C.; Pallini, A. (2001), Lepidoptera pests collected in Eucalyptus urophylla (Myrtaceae) plantations during five years in Três Marias, State of Minas Gerais, Brazil. Rev. Biol. Trop., 49, 1073-1082.

Saini, E.D. (1994), Aspectos morfologicos y biologicos de Podisus connexivus Bergroth (Heteroptera: Pentatomidae). Rev. Soc. Entomol. Argent., 53, 3542.

Santos, G.P.; Zanuncio, T.V.; Zanuncio, J.C. (2000), Desenvolvimento de Thyrinteina arnobia Stoll (Lepidoptera: Geometridae) em folhas de Eucalyptus urophylla e Psidium guajava. An. Soc. Entomol. Bras., 29, 13-22.

Sibly, R.M.; Calow, P. (1986), Physiological ecology of animals: an evolutionary approach. Blackwell Scientific, Oxford.

Sznajder, B.; Harvey, J.A. (2003), Second and third trophic level effects of differences in plant species reflect dietary specialisation of herbivores and their endoparasitoids. Entomol. Exp. Appl., 109, 73-82.

Thomas, D.B. (1992), Taxonomic synopsis of the Asopinae Pentatomidae (Heteroptera) of the Western Hemisphere. The Thomas Say Foundation, Entomological Society of America, Lanham.
Vacari, A.M.; Otuka, A.K.; DeBortoli, S.A. (2007), Desenvolvimento de Podisus nigrispinus (Dallas, 1851) (Hemiptera: Pentatomidae) alimentado com lagartas de Diatraea saccharalis (Fabricius,1794) (Lepidoptera: Crambidae). Arq. Inst. Biol., 74, 259265.

Zanuncio, J.C.; Alves, J.B.; Leite, J.E.M.; Silva, N.R.; Sartório, R.C. (1990), Desenvolvimento ninfal de Podisus connexivus Bergroth, 1891 (Hemiptera: Pentatomidae) alimentado com dois hospedeiros alternativos. Rev. Árvore, 14, 64-174.

Zanuncio, J.C.; Alves, J.B.; Santos, G.P.; Campos, W.O. (1993), Levantamento e flutuação populacional de lepidópteros associados a eucaliptocultura: VIRegião de Belo Oriente, Minas Gerais. Pesq. Agropec. Bras., 28, 1121-1127.

Zanuncio, J.C.; Guedes R.N.C.; Oliveira, H.N.; Zanuncio, T.V. (2002). Uma década de estudos com percevejos predadores: conquistas e desafios. In Controle biológico no Brasil: parasitóide e predadores. Manole, São Paulo, pp 495-505.

Zanuncio, T.V.; Saraiva, R.S.; Zanuncio, J.C.; Rodrigues, L.; Ferreira, J. (1991), Levantamento e flutuação populacional de lepidópteros associados a eucaliptocultura: XI - Região de Três Marias, M.G., junho/89 a maio/90. Rev. Cerne, 38, 373-382.

Zanuncio, T.V.; Zanuncio, J.C., Saavedra, J.L.D.; Lopes, E.D. (1996), Desenvolvimento de Podisus nigrispinus (Dallas) (Heteroptera: Pentatomidae) com Zophobas confusa Gebien (Coleoptera: Tenebrionidae) comparado à duas outras presas alternativas. Rev. Bras. Zool., 13, 159-164.

Zanuncio, T.V.; Torres, J.B.; Zanuncio, J.C.; Santos, G.P. (1998), Ciclo de vida e reprodução de Podisus distinctus (Stal) (Heteroptera: Pentatomidae) alimentado com dois tipos de presas. Rev. Bras. Entomol., 41, 335-337. 